\title{
Maioricimonas rarisocia gen. nov., sp. nov., a novel planctomycete isolated from marine sediments close to Mallorca Island
}

\author{
Elena Rivas-Marin • Sandra Wiegand • Nicolai Kallscheuer • Mareike Jogler • \\ Stijn H. Peeters • Anja Heuer • Mike S. M. Jetten • Christian Boedeker • \\ Manfred Rohde $\cdot$ Damien P. Devos $\cdot$ Christian Jogler
}

Received: 30 March 2020/Accepted: 11 June 2020/Published online: 25 June 2020

(C) The Author(s) 2020

\begin{abstract}
Planctomycetes are ubiquitous bacteria with environmental and biotechnological relevance. Axenic cultures of planctomycetal strains are the basis to analyse their unusual biology and largely uncharacterised metabolism in more detail. Here, we describe strain Mal4 ${ }^{\mathrm{T}}$ isolated from marine sediments close to Palma de Mallorca, Spain. Strain Mal4 ${ }^{\mathrm{T}}$ displays common planctomycetal features, such as division by polar budding and the presence of fimbriae and crateriform structures on the cell surface. Cell growth
\end{abstract}

E. Rivas-Marin · D. P. Devos

Centro Andaluz de Biología del Desarrollo, CSIC,

Universidad Pablo de Olavide, Seville, Spain

S. Wiegand

Institute for Biological Interfaces 5, Karlsruhe Institute of

Technology, Eggenstein-Leopoldshafen, Germany

N. Kallscheuer - S. H. Peeters - M. S. M. Jetten ·

C. Jogler

Department of Microbiology, Radboud Universiteit,

Nijmegen, The Netherlands

M. Jogler · C. Jogler $(\bowtie)$

Department of Microbial Interactions, Friedrich-Schiller

University, Jena, Germany

e-mail: christian.jogler@uni-jena.de

A. Heuer - C. Boedeker

Leibniz Institute DSMZ, Brunswick, Germany

M. Rohde

Central Facility for Microscopy, Helmholtz Centre for

Infection Research, Brunswick, Germany was observed at ranges of $10-39^{\circ} \mathrm{C}$ (optimum at 31 ${ }^{\circ} \mathrm{C}$ ) and $\mathrm{pH}$ 6.5-9.0 (optimum at 7.5). The novel strain shows as pear-shaped cells of $2.0 \pm 0.2 \times 1.4 \pm 0.1$ $\mu \mathrm{m}$ and is one of the rare examples of orange colonyforming Planctomycetes. Its genome has a size of 7.7 $\mathrm{Mb}$ with a $\mathrm{G}+\mathrm{C}$ content of $63.4 \%$. Phylogenetically, we conclude that strain Mal4 ${ }^{\mathrm{T}}$ (= DSM $100296^{\mathrm{T}}$ $=$ LMG $29133^{\mathrm{T}}$ ) is the type strain representing the type species of a novel genus, for which we propose the name Maioricimonas rarisocia gen. nov., sp. nov.

Keywords Marine bacteria - Planctomycetes - PVC superphylum · Mallorca coast · Planctomicrobium piriforme $\cdot$ Thalassoglobus

\section{Introduction}

Planctomycetes are bacteria that belong to the PVC superphylum (Wagner and Horn 2006), which includes the phyla Planctomycetes, Verrucomicrobia, Chlamydiae, Lentisphaerae and Kirimatiellaeota as well as some uncultured candidate phyla, such as Candidatus Omnitrophica. The PVC superphylum has environmental, medical and biotechnological relevance (Devos and Ward 2014).

Planctomycetes have been shown to be present in several environments, in which they play important roles in biogeochemical cycles, such as the carbon and nitrogen cycle (Wiegand et al. 2018). One example are 
Planctomycetes of the class Candidatus Brocadiae, which perform unique reactions during anaerobic ammonium oxidation (anammox) (Strous et al. 1999; Peeters and van Niftrik 2019). Members of the phylum Planctomycetes, in particular of the class Planctomycetia, colonise a variety of environments from terrestrial to aquatic, being able to dwell on various marine algal surfaces (Bengtsson et al. 2012; Bondoso et al. 2014, 2015, 2017; Lage and Bondoso 2014; Vollmers et al. 2017). They form biofilms on biotic surfaces (Bengtsson and Øvreås 2010), on which they metabolise complex carbon substrates (Lachnit et al. 2013; Jeske et al. 2013). Unique pili-forming crateriform structures and an enlarged periplasm are probably required for uptake and also cleavage of large polysaccharides obtained from the environment (Boedeker et al. 2017).

Planctomycetes possess large genomes with sizes of up to $12.4 \mathrm{Mb}$ (Ravin et al. 2018), in which the presence of giant genes has been reported (Jeske et al. 2013; Guo et al. 2014; Kohn et al. 2016; Faria et al. 2018). These genome sizes are in line with their assumed capacity for secondary metabolite production (Graça et al. 2016; Jeske et al. 2016; Yadav et al. 2018). Furthermore, several members of the phylum Planctomycetes produce carotenoids, which could be associated with an increased tolerance against UV radiation or oxidative stress (Kallscheuer et al. 2019b).

Planctomycetes were considered exceptional due to several presumptively eukaryotic features, such as the lack of a peptidoglycan (König et al. 1984), a compartmentalised cell plan (Lindsay et al. 1997), a nucleus-like structure (Fuerst and Webb 1991) and the endocytosis-like uptake of macromolecules for an intracellular degradation (Lonhienne et al. 2010). However, with advances of microscopy techniques and the development of genetic tools (Jogler et al. 2011; Rivas-Marín et al. 2016b; Boedeker et al. 2017), many of these traits have been refuted or reinterpreted.

In recent years, the presence of peptidoglycan has been reported in several members of the Planctomycetes (Jeske et al. 2015; van Teeseling et al. 2015) and also in the sister phyla Verrucomicrobia (Rast et al. 2017) and Chlamydiae (Pilhofer et al. 2013; Liechti et al. 2014, 2016). With the exception of anammox-performing Planctomycetes (Jogler 2014; Neumann et al. 2014), the proposed cell plan has been found to feature large invaginations of the cytoplasmic membrane instead of closed compartments
(Santarella-Mellwig et al. 2013; Acehan et al. 2014; Boedeker et al. 2017). These discoveries contributed to the reinterpretation of Planctomycetes as bacteria with a cell envelope architecture resembling that of Gram-negative bacteria, but with some variations (Devos 2014a, b; Boedeker et al. 2017). Nevertheless, Planctomycetes remain exceptional in other ways, e.g. they lack the protein FtsZ normally essential for bacterial division as well as other division proteins (Pilhofer et al. 2008; Jogler et al. 2012; Rivas-Marín et al. 2016a). Beyond that, phylum members divide by binary fission, budding or intermediate mechanisms (Wiegand et al. 2018, 2020). Presence and essentiality of sterols in the membranes of one of its members was recently reported (Pearson et al. 2003; Rivas-Marin et al. 2019).

The unusual cell biology of Planctomycetes prompted us to explore the uncharacterised planctomycetal diversity. In the present study, we describe the novel strain $\mathrm{Mal} 4^{\mathrm{T}}$ isolated from marine sediments in Palma de Mallorca (Spain) in terms of physiological, microscopic as well as genomic properties. Supported by phylogenetic analyses, we conclude that strain $\mathrm{Mal} 4^{\mathrm{T}}$ represents a novel species of a novel genus within the family Planctomycetaceae.

\section{Materials and methods}

\section{Cultivation conditions and isolation}

Strain $\mathrm{Ma} 4^{\mathrm{T}}$ was isolated from marine sediments at the coast of S'Arenal close to Palma de Mallorca (Spain) on the 23th of September 2014 (sampling location: $39.5126 \mathrm{~N} 2.7470 \mathrm{E}$ ) as previously described (Wiegand et al. 2020). For strain isolation and cultivation M1H NAG ASW medium was used. Medium preparation was previously described (Kallscheuer et al. 2019a). Cultures were incubated in baffled flasks at $28^{\circ} \mathrm{C}$ with constant agitation at 110 rpm. Plates were cultivated at $28^{\circ} \mathrm{C}$ for $2-3$ weeks and isolated colonies were then streaked on fresh $\mathrm{M} 1 \mathrm{H}$ NAG ASW plates. Initial amplification and sequencing of the 16S rRNA gene, intended to check whether isolated strains are members of the phylum Planctomycetes, was performed as previously described (Rast et al. 2017). 
Physiological analyses

Cultivations for physiological assays were performed in M1H NAG ASW medium. For $\mathrm{pH}$ optimum determination, $100 \mathrm{mM}$ 2-( $N$-morpholino)ethanesulfonic acid (MES) was used for cultivations at $\mathrm{pH}$ 5.0, 5.5, 6.0 and 6.5. For cultivations at $\mathrm{pH}$ values ranging from 7.0 to 8.0, MES was replaced by $100 \mathrm{mM} 4-(2-$ hydroxyethyl)-1-piperazine-ethanesulfonic acid (HEPES), whereas $100 \mathrm{mM}$ 3-(4-(2-Hydroxyethyl)piperazin-1-yl)-propane-1-sulfonic acid (HEPPS) served as a buffering agent at $\mathrm{pH} 8.5$ and $100 \mathrm{mM} \mathrm{N}$-cyclohexyl-2-aminoethanesulfonic acid (CHES) was used for $\mathrm{pH}$ maintenance at $\mathrm{pH} 9.0$ and 9.5. Cultivations for determination of the $\mathrm{pH}$ optimum were performed at $28{ }^{\circ} \mathrm{C}$. For temperature optimum determination, strain $\mathrm{Mal} 4^{\mathrm{T}}$ was cultivated at $\mathrm{pH} 8.0$ at different temperatures ranging from 10 to $39^{\circ} \mathrm{C}$. Cell growth and maximal growth rates were inferred from optical density measurements at $600 \mathrm{~nm}\left(\mathrm{OD}_{600}\right)$ of triplicate cultures.

Genome analysis

The genome of strain Mal4 ${ }^{\mathrm{T}}$ was previously published (Wiegand et al. 2020). The genome (accession number CP036275) and 16S rRNA gene sequence (accession number MK559979) are available from the GenBank database. The primary metabolism was analysed by examining locally computed InterProScan (Mitchell et al. 2019) results cross-referenced with information from the UniProt database (UniProt 2019) and BlastP results of 'typical' protein sequences. Numbers of carbohydrate-active enzymes were determined by employing dbCAN2 (Zhang et al. 2018), which automatically mines the CAZy database (Lombard et al. 2014).

Light microscopy and scanning electron microscopy

Phase contrast microscopy and scanning electron microscopy were performed according to protocols published earlier (Kallscheuer et al. 2019a).

Phylogenetic analyses

16S rRNA gene sequence-based phylogeny was computed for strain Mal4 ${ }^{\mathrm{T}}$, the type strains of all described planctomycetal species (assessed in January 2020) and all isolates recently published (Kohn et al. 2016, 2020a, b; Boersma et al. 2019; Kallscheuer et al. 2019a; Dedysh et al. 2020; Wiegand et al. 2020). An alignment of $16 \mathrm{~S}$ rRNA gene sequences was performed with SINA (Pruesse et al. 2012). The phylogenetic analysis was conducted employing a maximum likelihood approach with 1000 bootstraps, the nucleotide substitution model GTR, gamma distribution and estimation of proportion of invariable sites (GTRGAMMAI option) (Stamatakis 2014). Three 16S rRNA genes of bacterial strains from the PVC superphylum, but outside of the phylum Planctomycetes, were used as outgroup. The $r p o B$ nucleotide sequences (encoding the RNA polymerase $\beta$ subunit) were taken from publicly available genome annotations and the sequence identities were determined as described previously (Bondoso et al. 2013) using Clustal Omega (Sievers et al. 2011). Alignment and matrix calculation were done after extracting only those parts of the sequence that would have been sequenced with the described primer set. The average nucleotide identity (ANI) was calculated using OrthoANI (Lee et al. 2016). The average amino acid identity (AAI) was obtained with the aai.rb script of the enveomics collection (Rodriguez-R and Konstantinidis 2016). The percentage of conserved proteins (POCP) was calculated as described before (Qin et al. 2014). The unique single-copy core genome of all analysed genomes for the multi-locus sequence analysis (MLSA) was determined with proteinortho5 (Lechner et al. 2011) ('selfblast' option enabled). The sequences of the obtained orthologous groups were aligned using MUSCLE v.3.8.31 (Edgar 2004). After clipping, partially aligned $\mathrm{C}$ - and $\mathrm{N}$-terminal regions and poorly aligned internal regions were filtered using Gblocks (Castresana 2000). The final alignment was concatenated and clustered using the maximum likelihood method implemented by RaxML (Stamatakis 2014) with the 'rapid bootstrap' method and 500 bootstrap replicates.

\section{Results and discussion}

Phylogenetic inference

In the phylogenetic trees obtained after analysis of $16 \mathrm{~S}$ rRNA gene sequences, as well as MLSA (Fig. 1), 

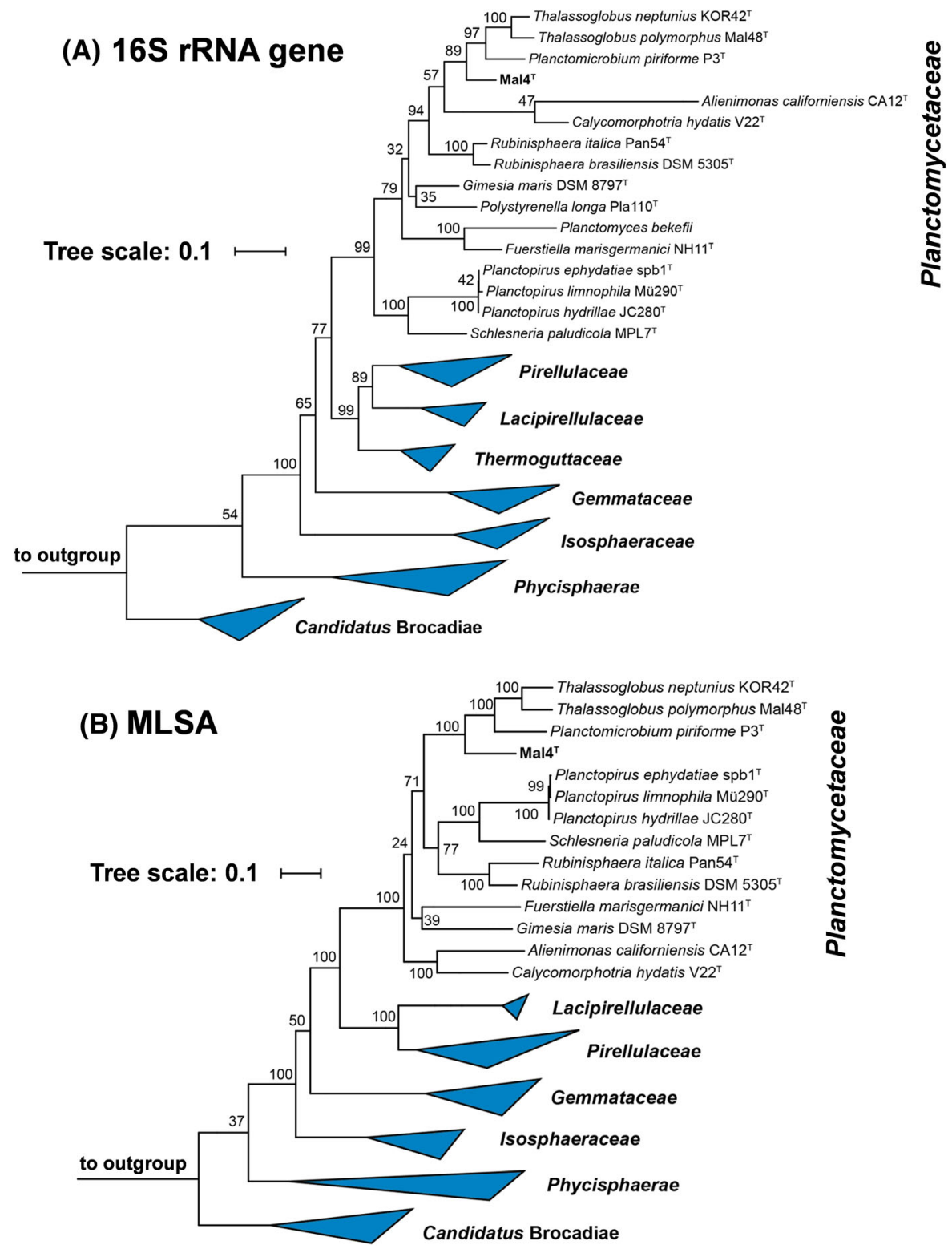

Fig. 1 Phylogenetic trees highlighting the position of strain Mal4 ${ }^{\mathrm{T}}$. The outgroup consists of three 16S rRNA genes from the PVC superphylum outside of the phylum Planctomycetes.

strain Mal4 ${ }^{\mathrm{T}}$ clusters stably with members of two genera of the family Planctomycetaceae, namely Planctomicrobium and Thalassoglobus. 16S rRNA gene sequence identity between strain $\mathrm{Mal}^{\mathrm{T}}$ and the two genera is between $91.4 \%$ and $91.9 \%$ (Fig. 2). These values are below the proposed genus threshold of $94.5 \%$, but above the threshold for separate families of $86.5 \%$ (Yarza et al. 2014), indicating that strain
Bootstrap values from 1000 re-samplings (500 re-samplings for MLSA) are given at the nodes (in \%)

$\mathrm{Mal} 4^{\mathrm{T}}$ represents an distinct genus in the family Planctomycetaceae. Coherently, average nucleotide identities (ANI) below 95\% confirm that strain Mal4 ${ }^{\mathrm{T}}$ is a distinct species. Phylogenetic assumptions on the genus level can also be obtained by analysing the $r p o B$ gene sequence identities, AAI and POCP. For delineation of genera, the proposed threshold values for the above-mentioned markers are 75.5-78\% (Kallscheuer 
16S rRNA gene

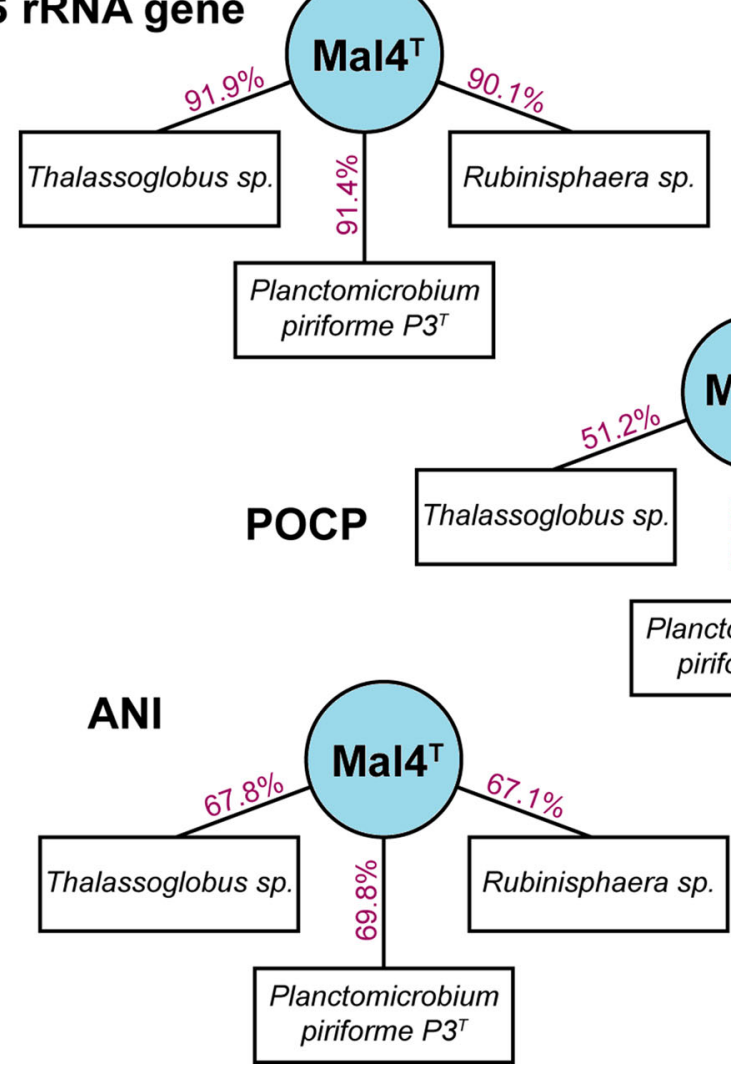

Fig. 2 Similarity values of the novel isolate $\mathrm{Mal} 4^{\mathrm{T}}$ in relation to species $P$. piriforme $\mathrm{P}^{\mathrm{T}}$, Thalassoglobus sp. and Rubinisphaera sp. Methods used: 16S rRNA gene sequence identity, rpoB gene

et al. 2019c), 45-65\% (Konstantinidis et al. 2017) and $50 \%$ (Qin et al. 2014), respectively. The rpoB identity value and the AAI between strain $\mathrm{Mal}^{\mathrm{T}}$ and the members of the genus Thalassoglobus, which comprises Thalassoglobus neptunius KOR42 ${ }^{\mathrm{T}}$ (Kohn et al. 2020a) and Thalassoglobus polymorphus Mal48 ${ }^{\mathrm{T}}$ (Rivas-Marin et al. 2020), are below the given thresholds. POCP was found to be slightly above the threshold $(51.2 \%)$, this, however, does not significantly influence the overall conclusion that strain $\mathrm{Mal} 4^{\mathrm{T}}$ belongs to a separate genus. Minimal comparative values of strain Mal4 $4^{\mathrm{T}}$ and the genus Rubinisphaera, another closely related genus; featuring Rubinisphaera italica (Kallscheuer et al. 2019a) and Rubinisphaera brasiliensis (Scheuner et al. 2014), are below these thresholds for all three phylogenetic markers (Fig. 2). Analogously, POCP between strain $\mathrm{Mal}^{\mathrm{T}}$ and Planctomicrobium piriforme $\mathrm{P}^{\mathrm{T}}$ (Kulichevskaya et al. 2015) was also found to fall below the

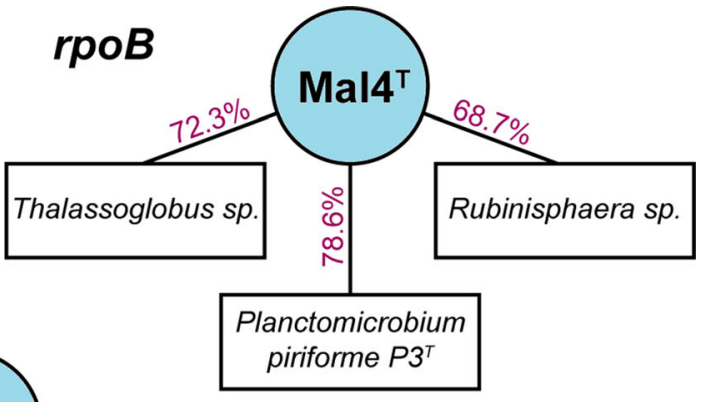

Mal4

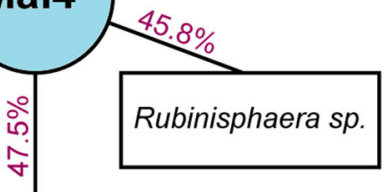

anctomicrobium

piriforme $P 3^{T}$

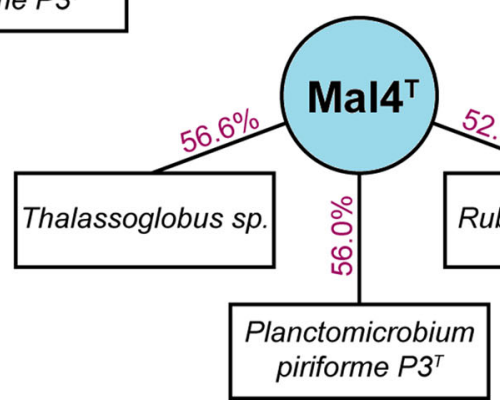

identity, percentage of conserved proteins (POCP), average nucleotide identity (ANI) and average amino acid identity (AAI)

proposed threshold (Fig. 2), whilst the AAI value (56\%) was in a 'grey zone' (45-65\%), but well below the upper limit. Although the $r p o B$ gene sequence identity of $78.6 \%$ is slightly above the proposed threshold, this sole deviance should not overrule the distinctiveness of the other values. In summary, the majority of analysed phylogenetic markers suggests that strain $\mathrm{Mal} 4^{\mathrm{T}}$ belongs to a novel genus.

Morphological and physiological analyses

Light microscopy and scanning electron microscopy (Fig. 3) were applied to analyse the morphological characteristic of $\mathrm{Mal} 4^{\mathrm{T}}$ cells harvested during the exponential growth phase. Detailed information on morphology and cell division is summarised in comparison to the current closest relatives (Table 1). $\mathrm{Mal}^{\mathrm{T}}$ cells are pear-shaped $(2.0 \pm 0.2 \mu \mathrm{m} \times 1.4 \pm$ $0.1 \mu \mathrm{m}$ ) (Fig. 3a-c), occur as single cells and in rare 

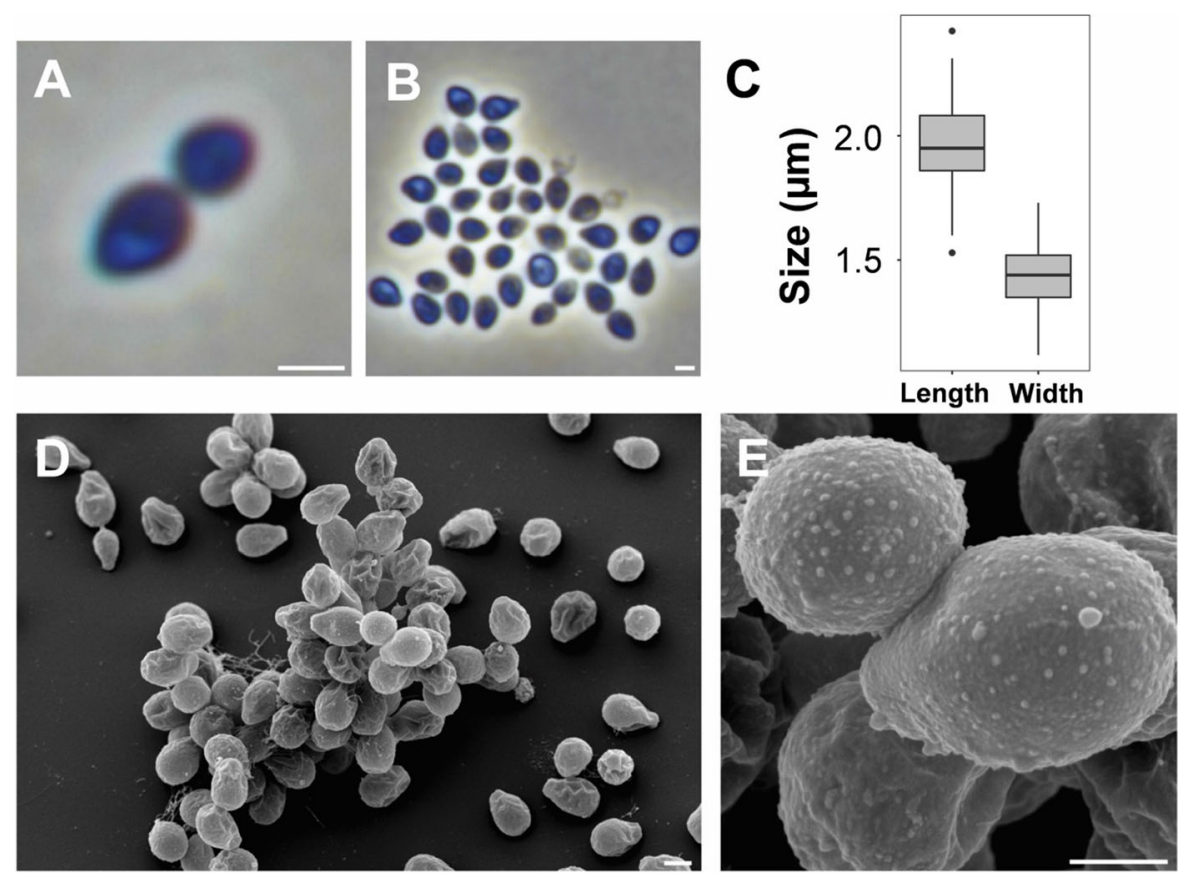

Fig. 3 Microscopy images and cell size plot of strain Mal4 ${ }^{\mathrm{T}}$. Pictures from light microscopy (a, b) and scanning electron microscopy $(\mathbf{d}, \mathbf{e})$ are shown. The scale bars are $1 \mu \mathrm{m}$. For

cases form aggregates (Fig. 3d). The cell surface appears rough, evenly covered with crateriform structures and short fimbriae (Fig. 3d, e). A holdfast structure was not observed during electron microscopy. As shown for all described members of the family Planctomycetaceae, cell division takes place by polar budding with the daughter cell displaying a round shape. Optimal temperature and $\mathrm{pH}$ for growth were shown to be $31{ }^{\circ} \mathrm{C}$ and $\mathrm{pH} 7.5$, respectively, however, $\mathrm{Mal} 4^{\mathrm{T}}$ cells are able to grow over a range of 10-39 ${ }^{\circ} \mathrm{C}$ and $\mathrm{pH}$ 6.5-9.0 (Fig. 4). These values are comparable to the two Thalassoglobus species, but differ from $P$. piriforme $\mathrm{P}^{\mathrm{T}}$, which did not grow at temperatures exceeding $30{ }^{\circ} \mathrm{C}$ and favours moderate acidic conditions. The maximal observed growth rate of strain Mal4 ${ }^{\mathrm{T}}$ in M1H NAG ASW medium was determined to be $0.041 \mathrm{~h}^{-1}$, corresponding to a generation time of approximately $17 \mathrm{~h}$. Strain Mal4 ${ }^{\mathrm{T}}$ is amongst the rare examples of planctomycetal strains forming orange colonies and might thus be an interesting strain for further analysis of carotenoid determination of the cell size (c) at least 100 representative cells were counted manually or by using a semi-automated object count tool

production and their function in Planctomycetes. Since most of the planctomycetal strains characterised so far are either pink to red or lack pigmentation (white), the pigmentation of the novel strain is an important phenotypic feature separating it from its current close phylogenetic neighbours. Strain Mal4 ${ }^{\mathrm{T}}$ is an aerobic heterotroph.

\section{Genomic characteristics}

The genomic characteristics of strain $\mathrm{Mal} 4^{\mathrm{T}}$ in comparison to $T$. polymorphus $\mathrm{Mal}^{\mathrm{T}}{ }^{\mathrm{T}}$, T. neptunius $\mathrm{KOR} 42^{\mathrm{T}}$ and $P$. piriforme $\mathrm{P} 3^{\mathrm{T}}$ are summarised in Table 1. Its genome is $7.7 \mathrm{Mb}$ in size, which is around $1 \mathrm{Mb}$ larger compared to the other three strains. The $\mathrm{G}+\mathrm{C}$ content is also the highest of the four strains. Automated gene prediction and annotation identified 5829 putative protein-encoding genes, of which $39 \%$ (2257 genes) are annotated as hypothetical proteins. These values correspond to 753 protein-coding genes per $\mathrm{Mb}$ and a coding density of $85.9 \%$. Although the 
Table 1 Phenotypic and genotypic features of strain $\mathrm{Mal4}^{\mathrm{T}}$ in comparison to its current closest relatives

\begin{tabular}{|c|c|c|c|c|}
\hline Characteristics & $\mathrm{Mal}^{\mathrm{T}}$ & $\begin{array}{l}\text { Thalassoglobus } \\
\text { polymorphus } \mathrm{Mal}^{\mathrm{T}} \mathrm{T}^{\mathrm{T}}\end{array}$ & $\begin{array}{l}\text { Thalassoglobus } \\
\text { neptunius KOR } 42^{\mathrm{T}}\end{array}$ & $\begin{array}{l}\text { Planctomicrobium } \\
\text { piriforme } \mathrm{P} 3^{\mathrm{T}} *\end{array}$ \\
\hline \multicolumn{5}{|l|}{ Phenotypic features } \\
\hline Color & Orange & Beige & Cream & White \\
\hline Size $(\mu \mathrm{m})$ & $2.0 \times 1.4$ & $1.6 \times 0.9$ & 1.7 (diameter) & $1.7-2.8 \times 0.9-1.3 \mu \mathrm{m}$ \\
\hline Shape & Pear-shaped & Pear-shaped & Spherical & $\begin{array}{l}\text { Ellipsoidal to pear- } \\
\text { shaped }\end{array}$ \\
\hline $\begin{array}{l}\text { Temperature range } \\
\text { (optimum) }\left({ }^{\circ} \mathrm{C}\right)\end{array}$ & $10-39(31)$ & $15-36(30)$ & $22-36(33)$ & $10-30(20-28)$ \\
\hline $\mathrm{pH}$ range (optimum) & $6.5-9.0(7.5)$ & $6.5-8.0(7.5)$ & $5.5-8.5(7.0-7.5)$ & $4.2-7.1(6.0-6.5)$ \\
\hline Aggregates & Yes & Yes & Yes & Yes \\
\hline Division & Budding & Budding & Budding & Budding \\
\hline Dimorphic life cycle & n.o. & n.o. & n.o. & Yes \\
\hline Flagella & n.o. & n.o. & n.o. & Yes \\
\hline Crateriform structures & Yes, overall & n.o. & Yes & Yes, polar \\
\hline Fimbriae & $\begin{array}{l}\text { Yes, overall matrix } \\
\text { or fibre }\end{array}$ & $\begin{array}{l}\text { Yes, overall matrix or } \\
\text { fibre }\end{array}$ & Few fibres & Yes \\
\hline Capsule & n.o. & n.o. & n.o. & n.d. \\
\hline Bud shape & Round & Like mother cell & Round & Like mother cell \\
\hline Budding pole & Polar & Polar & n.o. & Polar \\
\hline Stalk & Yes & Yes & n.o. & Yes \\
\hline Holdfast structure & n.o. & n.o. & Yes & Yes \\
\hline \multicolumn{5}{|l|}{ Genotypic features } \\
\hline Genome size (bp) & $7,744,989$ & $6,357,355$ & $6,734,412$ & $6,317,004$ \\
\hline Plasmids (bp) & No & No & n.d. & n.o. \\
\hline $\mathrm{G}+\mathrm{C}$ content $(\%)$ & 63.4 & 50.3 & 52.8 & 58.8 \\
\hline Protein-coding genes & 5829 & 4874 & 5508 & 5050 \\
\hline $\begin{array}{l}\text { Protein-coding genes/ } \\
\mathrm{Mb}\end{array}$ & 753 & 767 & 818 & 799 \\
\hline Hypothetical proteins & 2257 & 1987 & 2516 & 2814 \\
\hline Coding density (\%) & 85.9 & 84.9 & 85.7 & 85.8 \\
\hline 16S rRNA genes & 2 & 2 & 1 & 1 \\
\hline tRNA genes & 55 & 41 & 70 & 53 \\
\hline
\end{tabular}

*Genomic data from GenBank acc. no. NZ_FOQD00000000

n.o. not observed, n.d. not determined

genome size of strain $\mathrm{Mal}^{\mathrm{T}}$ is larger, the coding density is in the same range in the other three species. Similar to its relatives, the strain lacks plasmids. Numbers of 41-55 tRNA genes are similar, except for T. neptunius $\mathrm{KOR} 42^{\mathrm{T}}$, which has a slightly higher number of 70 tRNA genes. As for T. polymorphus $\mathrm{Mal} 48^{\mathrm{T}}$, strain Mal4 ${ }^{\mathrm{T}}$ harbours two copies of the $16 \mathrm{~S}$ rRNA gene, whereas the gene occurs in single copy in the other two strains. 

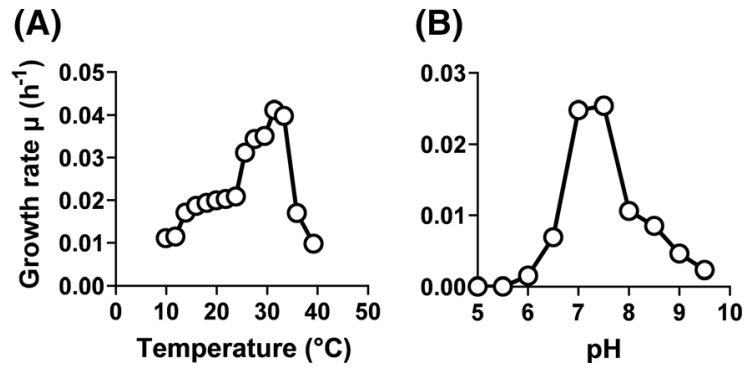

Fig. 4 Temperature and $\mathrm{pH}$ optima of strain $\mathrm{Mal} 4^{\mathrm{T}}$. Data points show average growth rates obtained after cultivation in $\mathrm{M} 1 \mathrm{H}$ NAG ASW medium in biological triplicates. Cultivations at different temperatures (a) were performed at $\mathrm{pH} 8$. Cultivations at different $\mathrm{pH}$ values (b) were conducted at $28{ }^{\circ} \mathrm{C}$

Genome-encoded features of the primary carbon metabolism

Based on the genome sequences, we analysed key metabolic capabilities in the primary metabolism of strain $\mathrm{Ma} 14^{\mathrm{T}}$ in comparison to the two Thalassoglobus species and $P$. piriforme $\mathrm{P}^{\mathrm{T}}$ (Table 2). Genes coding for enzymes participating in glycolytic pathways, gluconeogenesis, the tricarboxylic acid (TCA) cycle and anaplerotic reactions, such as pyruvate or phosphoenolpyruvate carboxylation and the glyoxylate shunt, were included. The resulting data suggest that strain $\mathrm{Mal} 4^{\mathrm{T}}$ is able to metabolise carbohydrates using at least two glycolytic pathways, the Embden-Meyerhof-Parnas pathway (the most common glycolytic pathway) and the pentose phosphate pathway. Additionally, its genome bears genes coding for putative 2-dehydro-3-deoxyphosphogluconate aldolase and phosphogluconate dehydratase, both involved in the alternative Entner-Doudoroff pathway. All four strains harbour a complete gene set required for a functional TCA cycle, which suggests that the central carbon metabolism of the strains is similar to canonical heterotrophic bacteria. With regard to gluconeogenesis, a minimal gene set required for this pathway has been identified, suggesting that the three strains are capable of de novo sugar biosynthesis. All four strains lack the glyoxylate shunt, which is typically required during growth either with acetate or with compounds that are degraded to acetate or acetyl-CoA units. The lack of the glyoxylate shunt suggests that the strains are not able to use such compounds as the exclusive energy and carbon source. Alternatively, they may follow a different pathway with a similar function.

Based on the physiological, morphological and phylogenetic analyses of strain Mal4 ${ }^{\mathrm{T}}$, we conclude that the characterised strain represents a novel species within the novel genus Maioricimonas. Thus, we propose the name Maioricimonas rarisocia gen. nov., sp. nov., represented by the type strain $M a 14^{\mathrm{T}}$.

Maioricimonas gen. nov.

Maioricimonas (Ma.io.ri.ci'mo.nas. M.L. fem. n. Maiorica of Mallorca; L. fem. n. monas a unit, monad; N.L. fem. n. Maioricimonas a monad from Mallorca, Spain).

Cells have a Gram-negative cell envelope architecture and divide by polar budding. Cells are mesophilic, neutrophilic, aerobic and heterotrophic and present crateriform structures and matrix or fimbriae. The genus is part of the family Planctomycetaceae, order Planctomycetales, class Planctomycetia, phylum Planctomycetes. The type species of the genus is Maioricimonas rarisocia.

\section{Maioricimonas rarisocia sp. nov.}

Maioricimonas rarisocia (ra.ri.so'ci.a. L. masc. adj. rarus few, infrequent; L. masc. adj. socius allied, united; N.L. fem. adj. rarisocia; corresponding to the characteristic of the cells to seldom form aggregates).

In addition to the features described for the genus, cells are pear-shaped $(2.0 \times 1.4 \mu \mathrm{m})$, form orange colonies and mostly occur as single cells. Temperature and $\mathrm{pH}$ optimum of the type strain are $31{ }^{\circ} \mathrm{C}$ and 7.5 , respectively, however growth is observed over a range 


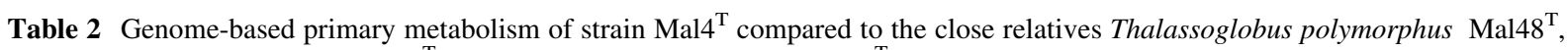
Thalassoglobus neptunius $\mathrm{KOR}_{4} 2^{\mathrm{T}}$ and Planctomicrobium piriforme $\mathrm{P}^{\mathrm{T}}$

\begin{tabular}{lllll}
\hline Enzyme & $\begin{array}{l}\text { EC } \\
\text { number }\end{array}$ & Gene & Mal4 $^{\mathrm{T}}$ & Mal48 $^{\mathrm{T}} \mathrm{KOR}^{\mathrm{T}} 2^{\mathrm{T}} \mathrm{P}^{\mathrm{T} *}$ \\
\hline
\end{tabular}

Glycolysis (Embden-Meyerhof-Parnas pathway)

Glucose-6-phosphate isomerase

ATP-dependent 6-phosphofructokinase isozyme 1

Fructose-bisphosphate aldolase class 2

Triosephosphate isomerase

Glyceraldehyde-3-phosphate dehydrogenase

Phosphoglycerate kinase

2,3-Bisphosphoglycerate-independent phosphoglycerate mutase

2,3-Bisphosphoglycerate-dependent phosphoglycerate mutase

Enolase

Pyruvate kinase I

Pyruvate dehydrogenase complex

Gluconeogenesis

Phosphoenolpyruvate synthase

Pyruvate, phosphate dikinase

Pyruvate carboxylase

Phosphoenolpyruvate carboxykinase (ATP)

Phosphoenolpyruvate carboxykinase (GTP)

Phosphoenolpyruvate carboxykinase (diphosphate)

Fructose-1,6-bisphosphatase class 2

Fructose-1,6-bisphosphatase class 1

Pyrophosphate-fructose 6-phosphate 1-phosphotransferase

Pentose phosphate pathway

Glucose-6-phosphate 1-dehydrogenase

6-Phosphogluconolactonase

6-Phosphogluconate dehydrogenase, decarboxylating

Transketolase 2

Transaldolase B

KDPG (Entner-Doudoroff pathway)

KDPG aldolase

Phosphogluconate dehydratase

TCA cycle

Citrate synthase

Aconitate hydratase A

Isocitrate dehydrogenase [NADP]
5.3.1.9 pgi Mal4_41440

2.7.1.11 pfkA Mal4_28800

4.1.2.13 fbaA Mal4_06980

5.3.1.1 tpiA Mal4_33520

1.2.1.12 gapA Mal4_10410

2.7.2.3 pgk Mal4_43170

5.4.2.12 gpmI Mal4_57980

$\begin{array}{llllll}\text { 5.4.2.11 } & \text { gpmA } & \mathrm{N} & \mathrm{N} & \mathrm{N} & \mathrm{Y}\end{array}$

4.2.1.11 eno Mal4_26950

2.7.1.40 pykF Mal4_16440

1.2.4.1/ aceEF Mal4_36650/Mal4_31770

2.3.1.12

2.7.9.2 $\quad$ ppsA $\quad \mathrm{N}$

2.7.9.1 $\quad$ ppdK Mal4_37310

6.4.1.1 pyc Mal4_02890

4.1.1.49 pckA Mal4_29720

4.1.1.32 pckG $\mathrm{N}$

4.1.1.38 PEPCK Mal4_57980

3.1.3.11 $\operatorname{glp} X \quad \mathrm{~N}$

3.1.3.11 fbp Mal4_30740

2.7.1.90 $\quad$ pfp Mal4_26620

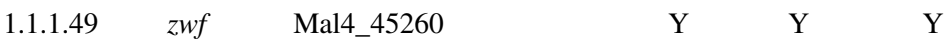

3.1.1.31 pgl Mal4_13550, Mal4_58700, $\quad \mathrm{Y} \quad \mathrm{Y} \quad \mathrm{Y}$

1.1.1.44 gndA Mal4_26580 $\quad$ Y $\quad$ Y $\quad$ Y

2.2.1.1 $t k t B \quad$ Mal4_57590/Ma14_57600 $\quad \mathrm{Y} \quad \mathrm{Y} \quad \mathrm{Y}$

$\begin{array}{llllll}2.2 .1 .2 & \text { talB } & \text { Mal4_01090 } & \text { Y } & \text { Y } & \text { Y }\end{array}$

$\begin{array}{llllll}\text { 4.1.2.14 } & \text { eda } & \text { Mal4_43780 } & \mathrm{Y} & \mathrm{Y} & \mathrm{Y} \\ \text { 4.2.1.12 } & \text { edd } & \text { Mal4_05000 } & \mathrm{Y} & \mathrm{Y} & \mathrm{Y}\end{array}$

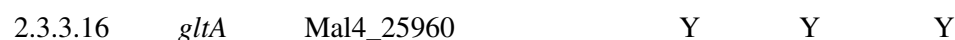

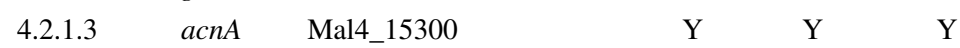

1.1.1.42 icd Mal4_26830 $\quad \mathrm{Y} \quad \mathrm{Y} \quad \mathrm{Y}$


Table 2 continued

\begin{tabular}{|c|c|c|c|c|c|c|}
\hline Enzyme & $\begin{array}{l}\text { EC } \\
\text { number }\end{array}$ & Gene & $\mathrm{Mal}^{\mathrm{T}}$ & Mal48 ${ }^{\mathrm{T}}$ & $\mathrm{KOR} 42^{\mathrm{T}}$ & $\mathrm{P} 3^{\mathrm{T}} *$ \\
\hline 2-Oxoglutarate dehydrogenase complex & $\begin{array}{l}1.2 .4 .2 / \\
2.3 .1 .61\end{array}$ & $s u c A B$ & Mal4_26900/Mal4_26910 & $\mathrm{Y}$ & $\mathrm{Y}$ & $\mathrm{Y}$ \\
\hline Succinate-CoA ligase complex & 6.2 .1 .5 & sucCD & Mal4_08670/Mal4_08660 & $\mathrm{Y}$ & $\mathrm{Y}$ & $\mathrm{Y}$ \\
\hline Succinate dehydrogenase complex & 1.3.5.1 & $s d h A B C$ & $\begin{array}{l}\text { Mal4_42560/ Mal4_42550/ } \\
\text { Mal4_42570 }\end{array}$ & $\mathrm{Y}$ & $\mathrm{Y}$ & $\mathrm{Y}$ \\
\hline Fumarate hydratase class I, an/aerobic & 4.2.1.2 & fum $A B$ & $\mathrm{~N}$ & $\mathrm{~N}$ & $\mathrm{~N}$ & n.a. \\
\hline Fumarate hydratase class II & 4.2.1.2 & fumC & Mal4_09530 & $\mathrm{Y}$ & $\mathrm{Y}$ & $\mathrm{Y}$ \\
\hline Malate dehydrogenase & 1.1.1.37 & $m d h$ & Mal4_25770 & $\mathrm{Y}$ & $\mathrm{Y}$ & $\mathrm{Y}$ \\
\hline \multicolumn{7}{|l|}{ Glyoxylate shunt } \\
\hline Isocitrate lyase & 4.1.3.1 & aceA & $\mathrm{N}$ & $\mathrm{N}$ & $\mathrm{N}$ & n.a. \\
\hline Malate synthase $G$ & 2.3.3.9 & $g l c B$ & $\mathrm{~N}$ & $\mathrm{~N}$ & $\mathrm{~N}$ & n.a. \\
\hline
\end{tabular}

*Genomic data from GenBank acc. no. NZ_FOQD00000000. Presence of a gene in strains used for comparison is indicated by 'Y' and absence is indicated by ' $\mathrm{N}$ '

n.a. not available

of $10-39{ }^{\circ} \mathrm{C}$ and $\mathrm{pH}$ 6.5-9.0. The type strain genome (accession number CP036275) and 16S rRNA gene (accession number MK559979) are available from GenBank. The genome of the type strain has a $\mathrm{G}+\mathrm{C}$ content of $63.4 \%$ and a size of $7.7 \mathrm{Mb}$.

The type strain is Mal4 ${ }^{\mathrm{T}}\left(=\mathrm{DSM} 100296^{\mathrm{T}}=\mathrm{LMG}\right.$ $29133^{\mathrm{T}}$, deposited as strain Malle4), isolated from marine sediments near the coast of S'Arenal in Palma de Mallorca, Mallorca Island, Spain.

Acknowledgements Open Access funding provided by Projekt DEAL. Part of this research was funded by the Deutsche Forschungsgemeinschaft (DFG) Grants KA 4967/11 and JO 893/4-1, Grant ALWOP.308 of the Nederlandse Organisatie voor Wetenschappelijk Onderzoek (NWO), SIAM (Soehngen Institute for Anaerobic Microbiology) Grant No. 024002002 and the Radboud Excellence fellowship. We thank Ina Schleicher for skillful technical assistance. We thank Brian Tindall and Regine Fähnrich from the DSMZ, as well as staff of the BCCM/LMG Bacteria collection, for support during strain deposition.

Author contributions E.R.M. wrote the manuscript, analysed the data and prepared the figures, S.W. and M.J. performed the genomic and phylogenetic analysis, A.H. isolated the strain and performed the initial strain cultivation and deposition, S.H.P. and C.B. performed the light microscopic analysis, N.K. and M.S.M.J. contributed to text preparation and revised the manuscript, M.R. performed the electron microscopic analysis, C.J. took the samples, supervised A.H. and the study. All authors read and approved the final version of the manuscript.

\section{Compliance with ethical standards}

Conflict of interest The authors declare that they have no conflict of interest.

Ethical statement This article does not contain any studies with animals performed by any of the authors.

Open Access This article is licensed under a Creative Commons Attribution 4.0 International License, which permits use, sharing, adaptation, distribution and reproduction in any medium or format, as long as you give appropriate credit to the original author(s) and the source, provide a link to the Creative Commons licence, and indicate if changes were made. The images or other third party material in this article are included in the article's Creative Commons licence, unless indicated otherwise in a credit line to the material. If material is not included in the article's Creative Commons licence and your intended use is not permitted by statutory regulation or exceeds the permitted use, you will need to obtain permission directly from the copyright holder. To view a copy of this licence, visit http://creativecommons.org/licenses/by/4.0/.

\section{References}

Acehan D, Santarella-Mellwig R, Devos DP (2014) A bacterial tubulovesicular network. J Cell Sci 127:277. https://doi. org/10.1242/jcs. 137596

Bengtsson MM, Øvreås L (2010) Planctomycetes dominate biofilms on surfaces of the kelp Laminaria hyperborea. BMC Microbiol 10:261. https://doi.org/10.1186/14712180-10-261

Bengtsson MM, Sjøtun K, Lanzén A, Ovreås L (2012) Bacterial diversity in relation to secondary production and 
succession on surfaces of the kelp Laminaria hyperborea. ISME J 6:2188-2198. https://doi.org/10.1038/ismej.2012. 67

Boedeker C, Schüler M, Reintjes G et al (2017) Determining the bacterial cell biology of Planctomycetes. Nat Commun 8:14853. https://doi.org/10.1038/ncomms14853

Boersma AS, Kallscheuer N, Wiegand S et al (2019) Alienimonas californiensis gen. nov. sp. nov., a novel Planctomycete isolated from the kelp forest in Monterey Bay. Antonie Van Leeuwenhoek. https://doi.org/10.1007/ s10482-019-01367-4

Bondoso J, Albuquerque L, Nobre MF et al (2015) Roseimaritima ulvae gen. nov., sp. nov. and Rubripirellula obstinata gen. nov., sp. nov. two novel planctomycetes isolated from the epiphytic community of macroalgae. Syst Appl Microbiol 38:8-15. https://doi.org/10.1016/j.syapm.2014. 10.004

Bondoso J, Balagué V, Gasol JM, Lage OM (2014) Community composition of the Planctomycetes associated with different macroalgae. FEMS Microbiol Ecol 88:445-456. https://doi.org/10.1111/1574-6941.12258

Bondoso J, Godoy-Vitorino F, Balagué V et al (2017) Epiphytic Planctomycetes communities associated with three main groups of macroalgae. FEMS Microbiol Ecol 93:fiw255. https://doi.org/10.1093/femsec/fiw255

Bondoso J, Harder J, Lage OM (2013) rpoB gene as a novel molecular marker to infer phylogeny in Planctomycetales. Antonie Van Leeuwenhoek 104:477-488. https://doi.org/ $10.1007 / \mathrm{s} 10482-013-9980-7$

Castresana J (2000) Selection of conserved blocks from multiple alignments for their use in phylogenetic analysis. Mol Biol Evol 17:540-552. https://doi.org/10.1093/oxfordjournals. molbev.a026334

Dedysh SN, Henke P, Ivanova AA et al (2020) 100-year-old enigma solved: identification, genomic characterization and biogeography of the yet uncultured Planctomyces bekefii. Environ Microbiol 22:198-211

Devos DP (2014a) PVC bacteria: variation of, but not exception to, the Gram-negative cell plan. Trends Microbiol 22:14-20. https://doi.org/10.1016/j.tim.2013.10.008

Devos DP (2014b) Re-interpretation of the evidence for the PVC cell plan supports a Gram-negative origin. Antonie Van Leeuwenhoek 105:271-274. https://doi.org/10.1007/ s10482-013-0087-y

Devos DP, Ward NL (2014) Mind the PVCs. Environ Microbiol 16:1217-1221. https://doi.org/10.1111/1462-2920.12349

Edgar RC (2004) MUSCLE: multiple sequence alignment with high accuracy and high throughput. Nucleic Acids Res 32:1792-1797. https://doi.org/10.1093/nar/gkh340

Faria M, Bordin N, Kizina J et al (2018) Planctomycetes attached to algal surfaces: insight into their genomes. Genomics 110:231-238. https://doi.org/10.1016/j.ygeno. 2017.10.007

Fuerst JA, Webb RI (1991) Membrane-bounded nucleoid in the eubacterium Gemmata obscuriglobus. Proc Natl Acad Sci USA 88:8184-8188. https://doi.org/10.1073/pnas.88.18. 8184

Graça AP, Calisto R, Lage OM (2016) Planctomycetes as novel source of bioactive molecules. Front Microbiol 7:1241. https://doi.org/10.3389/fmicb.2016.01241
Guo M, Zhou Q, Zhou Y et al (2014) Genomic evolution of 11 type strains within family Planctomycetaceae. PLoS ONE 9:e86752. https://doi.org/10.1371/journal.pone.0086752

Jeske O, Jogler M, Petersen J et al (2013) From genome mining to phenotypic microarrays: Planctomycetes as source for novel bioactive molecules. Antonie Van Leeuwenhoek 104:551-567. https://doi.org/10.1007/s10482-013-0007-1

Jeske O, Schüler M, Schumann P et al (2015) Planctomycetes do possess a peptidoglycan cell wall. Nat Commun 6:7116

Jeske O, Surup F, Ketteniß M et al (2016) Developing techniques for the utilization of Planctomycetes as producers of bioactive molecules. Front Microbiol 7:1242. https://doi. org/10.3389/fmicb.2016.01242

Jogler C (2014) The bacterial "mitochondrium". Mol Microbiol 94:751-755. https://doi.org/10.1111/mmi.12814

Jogler C, Glöckner FO, Kolter R (2011) Characterization of Planctomyces limnophilus and development of genetic tools for its manipulation establish it as a model species for the phylum Planctomycetes. Appl Environ Microbiol 77:5826-5829. https://doi.org/10.1128/AEM.05132-11

Jogler C, Waldmann J, Huang X et al (2012) Identification of proteins likely to be involved in morphogenesis, cell division, and signal transduction in Planctomycetes by comparative genomics. J Bacteriol 194:6419-6430. https:// doi.org/10.1128/JB.01325-12

Kallscheuer N, Jogler M, Wiegand S et al (2019a) Rubinisphaera italica sp. nov. isolated from a hydrothermal area in the Tyrrhenian Sea close to the volcanic island Panarea. Antonie Van Leeuwenhoek. https://doi.org/10.1007/ s10482-019-01329-w

Kallscheuer N, Moreira C, Airs R et al (2019b) Pink- and orange-pigmented Planctomycetes produce saproxanthintype carotenoids including a rare $\mathrm{C}_{45}$ carotenoid. Environ Microbiol Rep 11:741-748. https://doi.org/10.1111/17582229.12796

Kallscheuer N, Wiegand S, Peeters SH et al (2019c) Description of three bacterial strains belonging to the new genus Novipirellula gen. nov., reclassificiation of Rhodopirellula rosea and Rhodopirellula caenicola and readjustment of the genus threshold of the phylogenetic marker $r p o B$ for Planctomycetaceae. Antonie Van Leeuwenhoek. https:// doi.org/10.1007/s10482-019-01374-5

Kohn T, Heuer A, Jogler M et al (2016) Fuerstia marisgermanicae gen. nov., sp. nov., an unusual member of the phylum Planctomycetes from the German Wadden Sea. Front Microbiol 7:2079. https://doi.org/10.3389/fmicb. 2016.02079

Kohn T, Rast P, Wiegand S et al (2020a) The microbiome of Posidonia oceanica seagrass leaves can be dominated by Planctomycetes. Front Microbiol 11:1458. https://doi.org/ 10.3389/fmicb.2020.01458

Kohn T, Wiegand S, Boedeker C et al (2020b) Planctopirus ephydatiae, a novel Planctomycete isolated from a freshwater sponge. Syst Appl Mirobiol 43:126022. https://doi. org/10.1016/j.syapm.2019.126022

König E, Schlesner H, Hirsch P (1984) Cell wall studies on budding bacteria of the Planctomyces/Pasteuria group and on a Prosthecomicrobium sp. Arch Microbiol 138:200-205. https://doi.org/10.1007/BF00402120 
Konstantinidis KT, Rosselló-Móra R, Amann R (2017) Uncultivated microbes in need of their own taxonomy. ISME J 11:2399-2406. https://doi.org/10.1038/ismej.2017.113

Kulichevskaya IS, Ivanova AA, Detkova EN et al (2015) Planctomicrobium piriforme gen. nov., sp. nov., a stalked planctomycete from a littoral wetland of a boreal lake. Int $\mathbf{J}$ Syst Evol Microbiol 65:1659-1665. https://doi.org/10. 1099/ijs.0.000154

Lachnit T, Fischer M, Künzel S et al (2013) Compounds associated with algal surfaces mediate epiphytic colonization of the marine macroalga Fucus vesiculosus. FEMS Microbiol Ecol 84:411-420. https://doi.org/10.1111/1574-6941. 12071

Lage OM, Bondoso J (2014) Planctomycetes and macroalgae, a striking association. Front Microbiol 5:267. https://doi.org/ 10.3389/fmicb.2014.00267

Lechner M, Findeiß S, Steiner L et al (2011) Proteinortho: detection of (co-)orthologs in large-scale analysis. BMC Bioinformatics 12:124. https://doi.org/10.1186/14712105-12-124

Lee I, Ouk Kim Y, Park S-C, Chun J (2016) OrthoANI: an improved algorithm and software for calculating average nucleotide identity. Int $\mathrm{J}$ Syst Evol Microbiol 66:1100-1103. https://doi.org/10.1099/ijsem.0.000760

Liechti G, Kuru E, Packiam M et al (2016) Pathogenic Chlamydia lack a classical sacculus but synthesize a narrow, mid-cell peptidoglycan ring, regulated by MreB, for cell division. PLoS Pathog 12:e1005590-e1005590. https:// doi.org/10.1371/journal.ppat.1005590

Liechti GW, Kuru E, Hall E et al (2014) A new metabolic cellwall labelling method reveals peptidoglycan in Chlamydia trachomatis. Nature 506:507-510. https://doi.org/10.1038/ nature 12892

Lindsay M, Webb R, Fuerst J (1997) Pirellulosomes: a new type of membrane-bounded cell compartment in Planctomycete bacteria of the genus Pirellula. Microbiology 143:739-748

Lombard V, Golaconda Ramulu H, Drula E et al (2014) The carbohydrate-active enzymes database (CAZy) in 2013. Nucleic Acids Res 42:D490-D495. https://doi.org/10. 1093/nar/gkt1178

Lonhienne TGA, Sagulenko E, Webb RI et al (2010) Endocytosis-like protein uptake in the bacterium Gemmata obscuriglobus. Proc Natl Acad Sci USA 107:12883-12888. https://doi.org/10.1073/pnas. 1001085107

Mitchell AL, Attwood TK, Babbitt PC et al (2019) InterPro in 2019: improving coverage, classification and access to protein sequence annotations. Nucleic Acids Res 47:D351-D360. https://doi.org/10.1093/nar/gky1100

Neumann S, Wessels HJCT, Rijpstra WIC et al (2014) Isolation and characterization of a prokaryotic cell organelle from the anammox bacterium Kuenenia stuttgartiensis. Mol Microbiol 94:794-802. https://doi.org/10.1111/mmi. 12816

Pearson A, Budin M, Brocks JJ (2003) Phylogenetic and biochemical evidence for sterol synthesis in the bacterium Gemmata obscuriglobus. Proc Natl Acad Sci USA 100:15352-15357. https://doi.org/10.1073/pnas. 2536559100

Peeters SH, van Niftrik L (2019) Trending topics and open questions in anaerobic ammonium oxidation. Curr Opin
Chem Biol 49:45-52. https://doi.org/10.1016/j.cbpa.2018. 09.022

Pilhofer M, Aistleitner K, Biboy J et al (2013) Discovery of chlamydial peptidoglycan reveals bacteria with murein sacculi but without FtsZ. Nat Commun 4:2856

Pilhofer M, Rappl K, Eckl C et al (2008) Characterization and evolution of cell division and cell wall synthesis genes in the bacterial phyla Verrucomicrobia, Lentisphaerae, Chlamydiae, and Planctomycetes and phylogenetic comparison with rRNA genes. J Bacteriol 190:3192-3202. https:// doi.org/10.1128/JB.01797-07

Pruesse E, Peplies J, Glöckner FO (2012) SINA: accurate highthroughput multiple sequence alignment of ribosomal RNA genes. Bioinformatics 28:1823-1829. https://doi.org/ 10.1093/bioinformatics/bts252

Qin Q-L, Xie B-B, Zhang X-Y et al (2014) A proposed genus boundary for the prokaryotes based on genomic insights. J Bacteriol 196:2210-2215. https://doi.org/10.1128/JB. 01688-14

Rast P, Glöckner I, Boedeker C et al (2017) Three novel species with peptidoglycan cell walls form the new genus $\mathrm{Lacu}$ nisphaera gen. nov. in the family Opitutaceae of the verrucomicrobial subdivision 4. Front Microbiol 8:202. https://doi.org/10.3389/fmicb.2017.00202

Ravin NV, Rakitin AL, Ivanova AA et al (2018) Genome analysis of fimbriiglobus ruber SP5T, a planctomycete with confirmed chitinolytic capability. Appl Environ Microbiol 84:e02645-17

Rivas-Marín E, Canosa I, Devos DP (2016a) Evolutionary cell biology of division mode in the bacterial PlanctomycetesVerrucomicrobia-Chlamydiae superphylum. Front Microbiol 7:1964. https://doi.org/10.3389/fmicb.2016.01964

Rivas-Marín E, Canosa I, Santero E, Devos DP (2016b) Development of genetic tools for the manipulation of the planctomycetes. Front Microbiol. https://doi.org/10.3389/ fmicb.2016.00914

Rivas-Marin E, Stettner S, Gottshall EY et al (2019) Essentiality of sterol synthesis genes in the planctomycete bacterium Gemmata obscuriglobus. Nat Commun 10:2916. https:// doi.org/10.1038/s41467-019-10983-7

Rivas-Marin E, Wiegand S, Kallscheuer N et al (2020) Thalassoglobus polymorphus sp. nov., a novel Planctomycete isolated close to a public beach of Mallorca Island. Antonie van Leeuwenhoek. https://doi.org/10.1007/s10482-02001437-y

Rodriguez-R LM, Konstantinidis KT (2016) The enveomics collection: a toolbox for specialized analyses of microbial genomes and metagenomes. PeerJ Preprints 4:e1900v1. https://doi.org/10.7287/peerj.preprints.1900v1

Santarella-Mellwig R, Pruggnaller S, Roos N et al (2013) Threedimensional reconstruction of bacteria with a complex endomembrane system. PLoS Biol 11:e1001565. https:// doi.org/10.1371/journal.pbio.1001565

Scheuner C, Tindall BJ, Lu M et al (2014) Complete genome sequence of Planctomyces brasiliensis type strain (DSM $5305^{\mathrm{T}}$ ), phylogenomic analysis and reclassification of Planctomycetes including the descriptions of Gimesia gen. nov., Planctopirus gen. nov. and Rubinisphaera gen. nov. and emended descriptions of the order Planctomycetales and the family Planctomycetaceae. Stand Genomic Sci 9:10. https://doi.org/10.1186/1944-3277-9-10 
Sievers F, Wilm A, Dineen D et al (2011) Fast, scalable generation of high-quality protein multiple sequence alignments using Clustal Omega. Mol Syst Biol 7:539. https:// doi.org/10.1038/msb.2011.75

Stamatakis A (2014) RAxML version 8: a tool for phylogenetic analysis and post-analysis of large phylogenies. Bioinformatics 30:1312-1313. https://doi.org/10.1093/ bioinformatics/btu033

Strous M, Kuenen JG, Jetten MSM (1999) Key physiology of anaerobic ammonium oxidation. Appl Environ Microbiol 65:3248-3250

van Teeseling MCF, Mesman RJ, Kuru E et al (2015) Anammox Planctomycetes have a peptidoglycan cell wall. Nat Commun 6:6878. https://doi.org/10.1038/ncomms7878

Vollmers J, Frentrup M, Rast P et al (2017) Untangling genomes of novel Planctomycetal and verrucomicrobial species from monterey bay kelp forest metagenomes by refined binning. Front Microbiol 8:472. https://doi.org/10.3389/ fmicb.2017.00472

Wagner M, Horn M (2006) The Planctomycetes, Verrucomicrobia, Chlamydiae and sister phyla comprise a superphylum with biotechnological and medical relevance. Curr Opin Biotechnol 17:241-249. https://doi.org/10.1016/j. copbio.2006.05.005
Wiegand S, Jogler M, Boedeker C et al (2020) Cultivation and functional characterization of 79 planctomycetes uncovers their unique biology. Nat Microbiol 5:126-140. https://doi. org/10.1038/s41564-019-0588-1

Wiegand S, Jogler M, Jogler C (2018) On the maverick Planctomycetes. FEMS Microbiol Rev 42:739-760. https://doi. org/10.1093/femsre/fuy029

Yadav S, Vaddavalli R, Siripuram S et al (2018) Planctopirus hydrillae sp. nov., an antibiotic producing Planctomycete isolated from the aquatic plant Hydrilla and its whole genome shotgun sequence analysis. J Antibiot 71:575-583. https://doi.org/10.1038/s41429-018-0035-1

Yarza P, Yilmaz P, Pruesse E et al (2014) Uniting the classification of cultured and uncultured bacteria and archaea using 16S rRNA gene sequences. Nat Rev Microbiol 12:635-645. https://doi.org/10.1038/nrmicro3330

Zhang H, Yohe T, Huang L et al (2018) dbCAN2: a meta server for automated carbohydrate-active enzyme annotation. Nucleic Acids Res 46:W95-W101. https://doi.org/10. 1093/nar/gky418

Publisher's Note Springer Nature remains neutral with regard to jurisdictional claims in published maps and institutional affiliations. 